\title{
HUBUNGAN DUKUNGAN KELUARGA DAN PENERIMAAN DIRI DENGAN TINGKAT KECEMASAN PADA PASIEN PENYAKIT JANTUNG KORONER (PJK) DI POLI JANTUNG RUMAH SAKIT BIOMEDIKA MATARAM
}

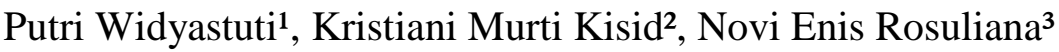 \\ ${ }^{1)}$ Mahasiswa Sekolah Tinggi Ilmu Kesehatan (STIKES) Mataram \\ ${ }^{2,3)}$ Staf Pengajar Sekolah Tinggi Ilmu Kesehatan (STIKES) Mataram \\ widyastutiputri92@gmail.com
}

\begin{abstract}
ABSTRAK
Penyakit Jantung Koroner (PJK) mempengaruhi kondisi fisik dan psikologis seseorang. Keluarga berperan penting dalam membantu masalah terkait kondisi psikologis pasien PJK terutama yang berkaitan dengan kecemasan. Hal tersebut ditunjukkan karena penderita PJK masih sulit menerima kondisi penyakit yang mereka alami. Penelitian ini bertujuan untuk mengetahui hubungan dukungan keluarga dan penerimaan diri dengan tingkat kecemasan pada pasien penyakit jantung koroner (PJK) di poli jantung RS. Biomedika Mataram.

Penelitian ini merupakan penelitian dengan menggunakan desain survey analitik dan pendekatan cross sectional dengan jumlah populasi sebanyak 216 pasien, sampel diambil menggunakan teknik purposive sampling sebanyak 139 pasien dengan menggunakan kuesioner. Untuk mengetahui hubungan variabel independen dan dependen digunakan uji analisis kolerasi spearman rank dengan $\alpha=0,05$.

Hasil analisis data keduanya menunjukkan $\mathrm{p}=0,000$ artinya Ha diterima yaitu ada hubungan dukungan keluarga dengan tingkat kecemasan pada pasien PJK dan ada hubungan penerimaan diri dengan tingkat kecemasan pada pasien PJK di poli jantung RS.Biomedika Mataram.

Hasil penelitian menunjukkan terdapat hubungan dukungan keluarga dengan tingkat kecemasan pada pasien PJK dengan koefisien kolerasi 0,730 yang berarti hubungan/kolerasi termasuk kuat dan terdapat pula hubungan penerimaan diri dengan tingkat kecemasan pada pasien PJK dengan koefiesien kolerasi 0,623 yang berarti hubungan/kolerasi termasuk kuat. Diharapkan bagi peneliti selanjutnya untuk meneliti faktor-faktor lain yang mempengaruhi dukungan keluarga seperti faktor emosi, spiritual, sosial ekonomi dan latar belakang budaya.
\end{abstract}

Kata kunci : Dukungan Keluarga, Kecemasan, Penerimaan Diri, PJK

\section{PENDAHULUAN}

Penyakit kardiovaskuler menjadi salah satu penyebab kematian secara global pada setiap tahunnya. Penyakit kardiovaskuler sendiri merupakan penyakit yang disebabkan adanya gangguan fungsi pada jantung serta pembuluh darah di dalam tubuh. Salah satu penyakit yang termasuk penyakit kardiovaskuler sendiri adalah Penyakit Jantung Koroner (PJK) (Kemenkes, 2014). Penyakit Jantung Koroner adalah penyakit jantung yang disebabkan penyempitan arteri koroner, mulai dari terjadinya arterosklerosis (kekakuan arteri) maupun yang sudah terjadi penimbunan lemak atau plak (plague) 
pada dinding arteri koroner, baik disertai gejala klinis atau tanpa gejala sekalipun (Kabo \& Karim, 2008).

Kemenkes (2017), menunjukkan data WHO pada tahun 2012, sebanyak 17,5 juta orang di dunia meninggal akibat penyakit kardiovaskuler atau 31\% dari 56,5 juta kematian di dunia. Adapun Survei Sample Registration System (SRS) pada tahun 2014, di Indonesia menunjukkan Penyakit Jantung Koroner (PJK) menjadi penyebab kematian tertinggi pada semua umur setelah stroke yakni sebesar 12,9\% (Kemenkes, 2017). Menurut data Riskesdas pada tahun 2013, berdasarkan diagnosis dokter, estimasi jumlah penderita PJK di NTB adalah 6.405 (Kemenkes, 2014). Berdasarkan sumber data yang diperoleh dari Rekam Medis Rumah Sakit Biomedika Mataram, angka kunjungan rata-rata pasien di Poliklinik Jantung selama 3 bulan terakhir dari bulan Juni sampai Agustus 2018 adalah 216 orang (Data Hasil Rekam Medis Rumah Sakit Biomedika 2018).

Pada dasarnya semua penyakit fisik akan mempengaruhi kondisi psikologik seseorang. Demikian juga penderita penyakit jantung koroner pada umumnya akan mengalami kondisi psikologik antara lain gangguan penyesuaian, kecemasan atau depresi (Hawari, 2011). Selain itu, kondisi keluarga dengan salah satu anggota keluarganya mengalami PJK merupakan suatu kondisi yang sulit bagi keluarga. PJK merupakan masalah keperawatan sebagai interpretasi dari penyakit kronis (Friedmen, Bowden \& Jones, 2010).

Keluarga merupakan support system utama dalam mempertahankan kesehatan. Peranan keluarga dalam perawatan antara lain menjaga dan merawat, mempertahankan dan meningkatkan status mental, mengantisipasi perubahan sosial ekonomi serta memberikan motivasi dan memfasilitasi kebutuhan spiritual (Maryam, 2010). Selain itu, dukungan keluarga dapat menimbulkan efek penyangga untuk efek-efek negatif dari stressor proses medikasi. Keluarga dianggap dapat memiliki pengaruh yang penting dalam membantu menyelesaikan masalah-masalah yang berkaitan dengan kesulitan hidup seperti menurunkan kecemasan (Setiadi, 2008).

Penelitian Huffman, Celano \& Januzzi (2010), menemukan bahwa terdapat peningkatan level kecemasan pada pasien penyakit jantung sebesar 16 $\%$ hingga $42 \%$ dibandingkan individu pada umumnya. Hal ini berkaitan pada penderita penyakit jantung yang kebanyakan dari mereka masih sulit untuk menerima diri dengan keadaan yang mereka alami sekarang. Hurlock (2002), menjelaskan bahwa seseorang yang menerima dirinya sendiri, mempunyai penilaian yang realistis terhadap adanya keterbatasan tanpa mencela dirinya dan sadar akan kemampuan serta secara bebas menggunakan kemampuannya tersebut dan tidak menyalahkan orang lain terhadap kekurangan yang dimiliknya.

Penelitian ini bertujuan untuk mengetahui apakah ada hubungan dukungan keluarga dan penerimaan diri dengan tingkat kecemasan pada pasien Penyakit Jantung Koroner (PJK) di poli Jantung Rumah Sakit Biomedika Mataram.

\section{BAHAN DAN METODE}

Desain penelitian yang digunakan dalam penelitian ini menggunakan desain survey analitik dengan pendekatan cross sectional. Jumlah sampel dalam penelitian ini adalah 139 pasien yang dilakukan di poli Jantung RS. Biomedika Mataram dengan teknik purposive sampling. Instrumen yang digunakan dalam penelitian ini 
menggunakan kuesioner. Uji statistik menggunakan Uji kolerasi Spearman Rank dengan menggunakan SPSS.

\section{HASIL}

Tabel 1. Distribusi Umur Responden

\begin{tabular}{|c|c|c|c|}
\hline No. & Umur (Th) & $\mathrm{n}$ & Persentase \\
\hline 1. & $26-35$ tahun & 4 & $2,9 \%$ \\
\hline 2. & $36-45$ tahun & 13 & $9,4 \%$ \\
\hline 3. & $46-55$ tahun & 21 & $15,1 \%$ \\
\hline 4. & $56-65$ tahun & 66 & $47,5 \%$ \\
\hline 5 & $\geq 65$ tahun & 35 & 25,1 \\
\hline \multicolumn{2}{|c|}{ Total } & 139 & $100 \%$ \\
\hline
\end{tabular}

Dari tabel 1 diperoleh sebagian besar responden berada pada umur 5665 tahun yaitu 66 orang $(47,5 \%)$.

Tabel 2. Distribusi Pendidikan Responden

\begin{tabular}{|c|c|c|c|}
\hline No. & Pendidikan & $\mathrm{n}$ & Persentase \\
\hline 1. & Tidak Sekolah & 3 & $2,2 \%$ \\
\hline 2. & SD & 39 & $28,1 \%$ \\
\hline 3. & SMP & 35 & $25,2 \%$ \\
\hline 4. & SMA & 45 & $32,4 \%$ \\
\hline 5. & Sarjana & 17 & $12,2 \%$ \\
\hline \multicolumn{2}{|c|}{ Total } & 139 & $100 \%$ \\
\hline
\end{tabular}

Dari tabel 2 diperoleh sebagian besar responden berpendidikan SMA yaitu 45 orang $(32,4 \%)$.

Tabel 3. Distribusi Pekerjaan Responden

\begin{tabular}{|c|c|c|c|}
\hline No. & Pekerjaan & $\mathrm{n}$ & Persentase \\
\hline 1. & PNS & 22 & $15,8 \%$ \\
\hline 2. & Wiraswasta & 30 & $21,6 \%$ \\
\hline 3. & Pedagang & 37 & $26,6 \%$ \\
\hline 4 & Petani & 10 & $7,2 \%$ \\
\hline 5. & IRT & 15 & $10,8 \%$ \\
\hline 6. & Lain-lain & 25 & $18 \%$ \\
\hline \multicolumn{2}{|c}{ Total } & 139 & $100 \%$ \\
\hline
\end{tabular}

Dari tabel 3 diperoleh sebagian besar responden bekerja sebagai pedagang yaitu 37 orang $(26,6 \%)$.

Tabel 4. Distribusi Status Keluarga dengan Pasien

\begin{tabular}{|c|c|c|c|}
\hline No. & $\begin{array}{c}\text { Hubungan dengan } \\
\text { Pasien }\end{array}$ & $\mathrm{n}$ & Persentase \\
\hline 1. & Suami & 16 & $11,5 \%$ \\
\hline 2. & Istri & 28 & $20,1 \%$ \\
\hline 3. & Anak & 56 & $40,3 \%$ \\
\hline 4. & Kakak & 9 & $6,5 \%$ \\
\hline 5. & Adik & 25 & $18 \%$ \\
\hline 6. & Cucu & 5 & $3,6 \%$ \\
\hline \multicolumn{2}{|r|}{ Total } & 139 & $100 \%$ \\
\hline
\end{tabular}

Dari tabel 4 diperoleh sebagian besar responden diantar oleh anaknya yaitu 56 orang $(40,3 \%)$.
Tabel 5. Distribusi Riwayat Serangan Angina

\begin{tabular}{|c|c|c|c|}
\hline No. & $\begin{array}{c}\text { Riwayat Serangan } \\
\text { Angina }\end{array}$ & $\mathrm{n}$ & Persentase \\
\hline 1. & 1 kali & 1 & $0,7 \%$ \\
\hline 2. & $2 \mathrm{kali}$ & 36 & $25,9 \%$ \\
\hline 3. & $3 \mathrm{kali}$ & 70 & $50,4 \%$ \\
\hline 4. & $4 \mathrm{kali}$ & 29 & $20,9 \%$ \\
\hline 5. & $5 \mathrm{kali}$ & 3 & $2,2 \%$ \\
\hline \multicolumn{2}{|c|}{ Total } & 139 & $100 \%$ \\
\hline
\end{tabular}

Dari tabel 5 diperoleh sebagian besar responden memiliki riwayat serangan angina $3 \mathrm{x}$ yaitu 70 orang $(50,4 \%)$.

Tabel 6. Distribusi Dukungan Keluarga

\begin{tabular}{|c|c|c|c|}
\hline No. & Dukungan keluarga & $\mathrm{n}$ & Persentase \\
\hline 1. & Baik & 58 & $41,7 \%$ \\
\hline 2. & Cukup & 76 & 54,7 \\
\hline 3. & Kurang & 5 & 3,6 \\
\hline & Total & 139 & $100 \%$ \\
\hline
\end{tabular}

Dari tabel 6 diperoleh sebagian besar responden memiliki dukungan keluarga cukup yaitu 76 orang $(54,7 \%)$. Tabel 7. Distribusi Penerimaan Diri

\begin{tabular}{|c|c|c|c|}
\hline No. & Penerimaan Diri & $\mathrm{n}$ & Persentase \\
\hline 1. & Sangat Tinggi & 8 & $5,8 \%$ \\
\hline 2. & Tinggi & 77 & $55,4 \%$ \\
\hline 3. & Sedang & 52 & $37,4 \%$ \\
\hline 4. & Rendah & 2 & $1,4 \%$ \\
\hline \multicolumn{2}{|c|}{ Total } & 139 & $100 \%$ \\
\hline
\end{tabular}

Dari tabel 7 diperoleh sebagian besar responden memiliki penerimaan diri tinggi yaitu 77 orang $(55,4 \%)$ Tabel 8. Distribusi Tingkat Kecemasan

\begin{tabular}{|c|c|c|c|}
\hline No. & $\begin{array}{c}\text { Kecemasan Pasien } \\
\text { PJK }\end{array}$ & $\mathrm{n}$ & Persentase \\
\hline 1. & Ringan & 50 & $36 \%$ \\
\hline 2. & Sedang & 86 & $61,9 \%$ \\
\hline 3. & Berat & 3 & $2,2 \%$ \\
\hline \multicolumn{2}{|c|}{ Total } & 139 & $100 \%$ \\
\hline
\end{tabular}

Dari tabel 8 diperoleh sebagian besar responden memiliki tingkat kecemasan sedang yaitu 86 orang $(61,9 \%)$.

\section{PEMBAHASAN}

Usia berpengaruh pada risiko penyakit kardiovaskuler, usia menyebabkan perubahan pada jantung dan pembuluh darah (Overbaugh, 2009).

Menurut Brown (2004), menjelaskan bahwa tingkat ekonomi 
yang rendah berdasarkan dengan pendapatan pribadi atau rumah tangga, pendidikan, pekerjaan dan area tempat tinggal berhubungan dengan rendahnya tingkat kesehatan baik fisik maupun emosi, hal ini dapat menyebabkan meningkatnya resiko penyakit kardiovaskuler salah satunya adalah PJK.

Kewajiban seorang anak adalah merawat keluarganya karena keluarga merupakan support system bagi pasien PJK dalam mempertahankan kesehatannya, peranan keluarga dalam perawatan antara lain menjaga atau merawat lansia, mempertahankan meningkatkan status mental, mengantisipasi perubahan sosial ekonomi, serta memberikan motivasi dan memfasilitasi kebutuhan spritual bagi lansia (Maryam, 2010).

Hasil penelitian menunjukkan bahwa pasien sindrom koroner akut mengalami angina berulang, hal ini disebabkan oleh beberapa faktor seperti usia, jenis kelamin, lama pengobatan, riwayat pengobatan, kolesterol tinggi dan kebiasaan merokok (Luthfiyaningtyas, 2016).

Dukungan keluarga menjadi faktor utama yang menentukan kepatuhan keluarga. Pendapat tersebut sesuai dengan pendapat bahwa dukungan keluarga bisa menentukan keyakinan dan nilai kesehatan individu serta dapat juga menemukan tentang program pengobatan yang dapat mereka terima. Keluarga juga memberi dukungan dan membuat keputusan mengenai perawatan dari anggota keluarga yang sakit, dukungan keluarga dianggap penting karena keluarga tidak dapat dilepaskan dalam standar tindakan keperawatan antara intervensi atau implementasi terhadap klien dan keluarganya (Niven, 2002).

Agustini (2016) menyatakan bahwa subjek penyakit jantung tersebut memiliki keyakinan yang kuat untuk dapat sembuh dari penyakitnya karena memiliki hubungan yang baik dengan keluarga. Selain itu, subjek juga tidak menyesali dengan penyakit yang telah dideritanya tersebut sehingga ia dapat menerima kondisi yang dialami.

Pasien PJK yang menjalani rawat jalan kemungkinan sudah memiliki strategi koping yang baik sehingga kecemasannya sedikit berkurang. Hal tersebut dapat dilihat dari segi kesehatan fisik, keyakinan atau pandangan positif, keterampilan sosial, dan dukungan sosial (Nasir \& Muhith, 2011).

Berdasarkan hasil uji statistik Spearman rank test dengan bantuan SPSS v.16 diinterpretasikan sebagai berikut: nilai dari Spearman's rho diperoleh nilai p-value adalah 0,000 . Dimana $(\alpha)<0,05$ dengan $r$ hitung sebesar 0,730 , sehingga dapat diambil kesimpulan Ho ditolak dan Ha diterima, berarti terdapat hubungan yang signifikan antara dukungan keluarga dengan tingkat kecemasan pada pasien PJK di poli jantung RS.Biomedika Mataram.

Penelitian yang dilakukan Isrofah (2016), menyatakan bahwa dukungan keluarga sangat diperlukan oleh setiap individu di dalam setiap siklus kehidupannya. Dukungan dari keluarga akan semakin dibutuhkan pada saat seseorang sedang menghadapi masalah atau sakit, dalam hal ini peran keluarga diperlukan untuk menjalanimasa-masa sulit dengan cepat.

Hasil penelitian tersebut sesuai dengan teori dukungan dari keluarga merupakan unsur terpenting dalam membantu individu menyelesaikan masalah. Apabila ada dukungan, rasa percaya diri akan bertambah dan motivasi untuk menghadapi masalah yang akan terjadi akan meningkat. Selain itu ada faktor eksternal lainnya yaitu dukungan sosial sebagai sumber 
koping, dimana kehadiran orang lain dapat membantu seseorang mengurangi kecemasan dan juga ancaman integritas diri, meliputi ketidaknyamanan fisiologis atau gangguan terhadap kebutuhan dasar (penyakit yang diderita, trauma fisik, kehilangan serta status atau peran) (Stuart \& Sundeen, 2013).

Hasil uji statistik analisa kedua Spearman rank test dengan bantuan SPSS v.16 diinterpretasikan sebagai berikut: nilai dari Spearman's rho diperoleh nilai p-value adalah 0,000 . Dimana $(\alpha)<0,05$ dengan $r$ hitung sebesar 0,623 , sehingga dapat diambil kesimpulan Ho ditolak dan Ha diterima, berarti terdapat hubungan yang signifikan antara penerimaan diri dengan tingkat kecemasan pada pasien PJK di poli jantung RS. Biomedika Mataram.

Hasil penelitian ini sejalan dengan penelitian dalam jurnal "Psychoterapy Didabled Petients" yang menyebutkan bahwa tampak dari luar, turunnya penerimaan diri akan menciptakan perubahan yang drastis pada kehidupan seseorang, sehingga konflik yang dihadapi oleh pasien PJK menyebabkan timbulnya kecemasan dalam bergerak dan perilaku regresif, atau yang mungkin tampak dari luar adalah hubungan sosial yang terganggu (Potocka et al, 2009). Artinya, semakin individu dengan PJK tidak mampu untuk menerima keadaan dirinya maka konflik yang dihadapi individu PJK adalah timbulnya kecemasan atau rasa cemas yang dirasakannya individu PJK semakin tinggi.

\section{SIMPULAN DAN SARAN}

\section{Kesimpulan:}

1. Terdapat hubungan antara dukungan keluarga dengan tingkat kecemasan pada pasien PJK dengan p-value 0,000 dan hubungan/kolerasi termasuk kuat.
2. Terdapat hubungan antara penerimaan diri dengan tingkat kecemasan pada pasien PJK dengan p-value 0,000 dan hubungan/kolerasi termasuk kuat.

\section{Saran:}

Dalam penelitian ini peneliti hanya mengambil data dari respoden/pasien saja, diharapkan bagi peneliti selanjutnya untuk dapat meneliti faktorfaktor lain yang mempengaruhi dukungan keluarga seperti: faktor emosi, spiritual, sosial ekonomi dan latar belakang budaya dengan melibatkan keluarganya pula agar data yang diperoleh lebih valid.

\section{DAFTAR PUSTAKA}

Agustini, M. 2016. Self-Efficacy dan Makna Hidup pada Penderita Penyakit Jantung Koroner. eJournal Psikologi. 4(4). 419-430.

Data Hasil Rekam Medis Rumah Sakit Biomedika 2018

Friedman, MM, Bowden, O \& Jones, M. 2010. Buku Ajar Keperawatan Keluarga: riset, teori dan praktik; Alih bahasa, Achir Yani S.Hamid...[et al]; editor edisi Bahasa Indonesia, Estu Tiar, Ed.S. Jakarta: EGC

Hawari, D. 2011. Stres, Depresi dan Cemas. Jakarta: EGC

Huffman, J.C., Celano.C.M., \& Januzzi , J.L. 2010. The Relationship Between Depression, Anxiety, and Cardiovascular Outcames in Patients With Acute Coronary Syndromes. Neuropychiatric Disease and Treatment. (64).15-18

Hurlock, E.B. 2002. Psikologi Perkembangan, $5^{\text {th }}$ edition. Erlangga: Jakarta.

Isofah. 2016. Hubungan Dukungan Keluarga dengan Kecemasan Ibu 
dari anak yang menderita Bronkopneumonia di BPKM Kota Pekalongan. Poltekkes Kemenkes Semarang. Semarang

Luthfiyaningtyas, dkk. 2016. Hubungan

Dukungan Keluarga dengan

Tingkat Kecemasan pada Pasien Sindrom Koroner Akut di RSUP Tugurejo Semarang. Fakultas Kedokteran Universitas Diponegoro: Semarang

Maryam, S., dkk. 2010. Asuhan Keperawatan Pada Lansia. Jakarta: Trans Info Medika.

Nasir, A dan Muhith, A. (2011). DasarDasar Keperawatan Jiwa. Jakarta : Salemba Medika

Kabo, P dan Karim, S. 2008. EKG dan Penanggulangan Beberapa Penyakit Jantung Untuk Dokter Umum. Jakarta: Balai Penerbit Fakultas Kedokteran Universitas Indonesia.

Kementerian Kesehatan RI. 2014. Situasi Kesehatan Jantung. Jakarta Selatan: Pusat Data dan Informasi Kementerian Kesehatan RI

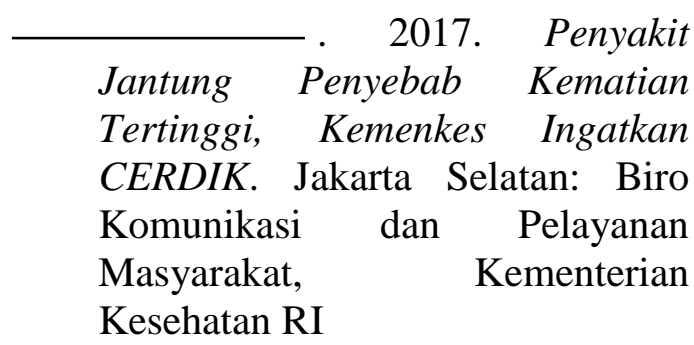

Niven N. 2002. Psikologi Kesehatan Pengantar Untuk Perawat dan Profesionalisme Kesehatan Lain. Jakarta: EGC

Overbaugh KJ, 2009, "Acute Coronary Syndrome”, ajn online, vol 109, no 5.

Potocka, A., Jablonska, Turczyn K., \& Merecz, D. (2009). "Psychological Correlates of Quality of Life in Dermatology Patients: The Role of Mental Health and SelfAcceptance ". Acta Dermatoven APA. Vol 18. No 2. Hlm. 53-62
Setiadi. (2008). Konsep dan Proses Keperawatan Keluarga. Yogyakarta: Graha Ilmu

Stuart \& Sundeen. 2013. Keperawatan Jiwa Edisi 6. EGC: Jakarta 